\title{
ANTIDIABETIC AND CYTOTOXICITY SCREENING OF FIVE MEDICINAL PLANTS USED BY TRADITIONAL AFRICAN HEALTH PRACTITIONERS IN THE NELSON MANDELA METROPOLE, SOUTH AFRICA
}

\author{
Mea van Huyssteen ${ }^{1}$, Pieter J Milne ${ }^{1}$, Eileen E Campbell ${ }^{2}$ and Maryna van de Venter ${ }^{3^{*}}$ \\ ${ }^{1}$ Department of Pharmacy, ${ }^{2}$ Department of Botany, ${ }^{3}$ Department of Biochemistry and \\ Microbiology, PO Box 77000, Nelson Mandela Metropolitan University, Port Elizabeth 6031, \\ South Africa \\ E-mail: *maryna.vandeventer@nmmu.ac.za
}

\begin{abstract}
Diabetes mellitus is a growing problem in South Africa and of concern to traditional African health practitioners in the Nelson Mandela Metropole, because they experience a high incidence of diabetic cases in their practices. A collaborative research project with these practitioners focused on the screening of Bulbine frutescens, Ornithogalum longibracteatum, Ruta graveolens, Tarchonanthus camphoratus and Tulbaghia violacea for antidiabetic and cytotoxic potential. In vitro glucose utilisation assays with Chang liver cells and $\mathrm{C} 2 \mathrm{C} 12$ muscle cells, and growth inhibition assays with Chang liver cells were conducted. The aqueous extracts of Bulbine frutescens (143.5\%), Ornithogalum longibracteatum (131.9\%) and Tarchonanthus camphoratus (131.5\%) showed significant increased glucose utilisation activity in Chang liver cells. The ethanol extracts of Ruta graveolens (136.9\%) and Tulbaghia violacea (140.5\%) produced the highest increase in glucose utilisation in C2C12 muscle cells. The ethanol extract of Bulbine frutescens produced the most pronounced growth inhibition (33.3\%) on Chang liver cells. These findings highlight the potential for the use of traditional remedies in the future for the management of diabetes and it is recommended that combinations of these plants be tested in future.
\end{abstract}

Keywords: Diabetes mellitus; Cytotoxicity; Collaborative research; Chang liver cells; C2C12 muscle cells.

\section{Introduction}

South African epidemiological data on diabetes mellitus show an increased incidence of diabetes in urban areas as compared to rural areas and interestingly report a strong genetic component for the development of diabetes in Xhosa-speaking people in the Eastern Cape (Molleutze and Levitt, 2005). The focus of this article is on the potential of medicinal plants used by traditional health practitioners in the Nelson Mandela Metropole to influence glucose utilisation in cells. These experiments were done in an interactive research setting which included collaborating practitioners in the investigative process (van Huyssteen et al., 2004).

Medicinal plants were selected for the study according to their favourable sustainable cultivation profiles established through a jointly developed medicinal garden and included Bulbine frutescens (L.) Wild. (Asphodelaceae), Ornithogalum longibracteatum Jacq. (Ornithogaloideae: Hyacinthaceae), Ruta graveolens L. (Rutaceae), Tarchonanthus camphoratus L. (Asteraceae) and Tulbaghia violacea Harv. (Alliaceae). In addition, ethnobotanical data on $R$. graveolens reported its use in the management of diabetes mellitus in the Bredasdorp/Elim area, Southern Cape, South Africa (Thring and Weitz, 2006). Furthermore, Allium sativum L. has been used for diabetes in traditional Indian medicine (Mukherjee et al., 2006), which might indicate some potential for T. violacea because the plants belong to the same family and possess a number of similar active ingredients (Cox and Ballick, 1994; Motsei et al., 2003). Interestingly, practitioners told us that they used T. camphoratus in remedies for diabetes and this was also documented among communities living in the George/Knysna area (Southern Cape, South Africa) by Yvette van Wijk (personal communication). Water and ethanol were used as extraction solvents because collaborating practitioners used water as vehicle for most of their remedies, which was supported by numerous literature citings (Eloff 1998; Grierson and Afolayan, 1999; Inngjerdingen et al., 2004; Kelmanson et al., 2004; Shale et al., 1999). The second extraction solvent was ethanol, because it is relatively inexpensive and freely available to practitioners (Louw et al., 2002). 
The objectives of the study were to test aqueous and ethanol extracts of these plants for in vitro glucose utilisation activity into $\mathrm{C} 2 \mathrm{C} 12$ muscle and Chang liver cells and cytotoxic activity in Chang liver cells. The focus point of which was to share the results with participating practitioners in order to develop and promote transparent research within the collaboration boundaries.

\section{Methodology \\ Plant material collection and extraction procedures}

All the plants were collected from the Nelson Mandela Metropolitan NMM area. Plant material was collected in the early morning, kept in closed plastic bags and extracted fresh as soon as possible after harvesting $(<2$ hours after collection). Freshly harvested plant material was macerated in either deionised water or $99 \%$ ethanol at room temperature in just enough solvent to cover it. The solvent was replaced every $24 \mathrm{hrs}$ for three days. Extracts were then vacuum-filtered through Whatman No1 filters. Ethanol extracts were concentrated in a rotary evaporator at a temperature of $\leq 67^{\circ} \mathrm{C}$ for a maximum of three hours. Concentrated ethanol extracts that were not yet dry after three hours and aqueous extracts were freeze-dried. Dried extracts were stored in $50 \mathrm{ml}$ polypropylene tubes in the dark at $4^{\circ} \mathrm{C}$ in a desiccator. Table 1 summarises the plant parts used, month of collection, yield of dried extract in the case of aqueous extracts and authentication of the plant. In the case of ethanol extracts, yields were not calculated, because the dried extracts stuck to the round bottom flasks in which they were evaporated and could not be removed in an accurate fashion. For this reason only the starting weights of the plant material were recorded for the ethanol extracts (Table 1).

Table 1: Plant material extraction data.

\begin{tabular}{|l|c|c|c|l|}
\hline Name & Plant part & $\begin{array}{c}\text { Month of } \\
\text { collection }\end{array}$ & $\begin{array}{c}\text { Aqueous yield (w/w) } \\
\text { (Ethanol starting } \\
\text { weight) }\end{array}$ & Authentication \\
\hline Bulbine frutescens & Whole & January & $\begin{array}{c}2.05 \% \\
(51.92 \mathrm{~g})\end{array}$ & None \\
\hline $\begin{array}{l}\text { Ornithogalum } \\
\text { longibracteatum }\end{array}$ & Bulb & June & $\begin{array}{c}1.14 \% \\
(646.95 \mathrm{~g})\end{array}$ & $\begin{array}{l}\text { Dr D du Preez } \\
\text { Dept of Botany } \\
\text { NMMU }\end{array}$ \\
\hline Ruta graveolens & Arial parts & December & $12.67 \%$ & None \\
\hline Tarchonanthus & Leaves & October & $6.45 \%$ & Identified tree on campus \\
camphoratus & /soft twigs & October & $2.06 \mathrm{~g})$ & Prof E Campbell \\
\hline Tulbaghia violacea & Whole & Dept of Botany \\
& & & $(40.93 \mathrm{~g})$ & NMMU \\
\hline
\end{tabular}

\section{Routine maintenance of cell cultures}

Chang liver cells and $\mathrm{C} 2 \mathrm{C} 12$ muscle cells were maintained in $10 \mathrm{~cm}$ culture dishes and incubated at $37^{\circ} \mathrm{C}$ in a $5 \% \mathrm{CO}_{2}$ environment. Growth medium consisted of RPMI-1640 (BioWhittaker, Walkerville, USA) supplemented with $10 \%$ fetal bovine serum (fbs; Delta Bioproducts, Johannesburg, South Africa). Growth medium was changed every 48 to 72 hrs. When about $70 \%$ confluence was reached, cells were detached by washing with phosphatebuffered saline-A (PBSA) and incubating with trypsin $0.25 \%(\mathrm{v} / \mathrm{v})$ in PBSA (Roche Diagnostics, Manheim, Germany). Cells were routinely divided at a split ratio of one in six.

\section{Glucose utilisation in C2C12 muscle cells}

C2C12 muscle cells were seeded into flat-bottom 96-well culture plates (NUNC, Roskilde, Denmark) at a density of 5000 cells/well in a volume of $200 \mu \mathrm{l} /$ well growth medium. The plates were incubated for three and a half days at $37^{\circ} \mathrm{C}$ without changing the medium. On the day of the assay all reagents were made up with incubation buffer (RPMI-1640 with an adjusted glucose concentration of $8 \mathrm{mM}$ using phosphate-buffered saline (PBS) plus $0.1 \%$ $(\mathrm{m} / \mathrm{v}) \mathrm{BSA})$. The spent growth medium was aspirated and $50 \mu \mathrm{l}$ of incubation buffer with or without insulin $(1 \mu \mathrm{M}$; Human, recombinant; Roche, Penzberg, Germany) or test samples $(0.5$ and $50 \mu \mathrm{g} / \mathrm{ml})$ were added to each well. The plates were incubated for one hour at $37^{\circ} \mathrm{C}$. After incubation, $10 \mu \mathrm{l}$ aliquots were taken from each well and transferred to an empty 96-well microtiter plate. Two hundred microliters of the glucose oxidase reagent (Sera-pak Plus, Hong Kong) was added to each $10 \mu \mathrm{l}$ aliquot and developed for 15 minutes at $37^{\circ} \mathrm{C}$. The plate was read after development at $492 \mathrm{~nm}$ in a multiplate reader (Multiscan $\mathrm{MS}^{\circledR}$ version 4.0 Labsystem $^{\circledR}$ type 352). 
Glucose standards were run with each experiment. The standards were made up with the incubation buffer (containing $0.1 \%(\mathrm{~m} / \mathrm{v}) \mathrm{BSA}$ ) at concentrations of 2, 4, 6 and $7 \mathrm{mM}$ diluted with PBS. PBS was also used as the blank. The glucose concentration $( \pm 8 \mathrm{mM})$ in the incubation buffer given to the cells at zero time, was also determined with the same method. Results were expressed as percentage glucose uptake as compared to control cells of which the glucose uptake was assigned as $100 \%$.

$$
\% \mathrm{GU}=\frac{\left(\mathrm{Avg}: \mathrm{T}_{0}-\mathrm{TS}\right)}{\left[\text { Avg: }\left(\text { Avg } \mathrm{T}_{0}-\mathrm{NC}\right)\right]} \times 100 \%
$$

Key: Avg = average; GU = glucose uptake or utilisation; $\mathrm{NC}=$ negative control measurement;

$\mathrm{T}_{0}=$ zero time measurement; $\mathrm{TS}=$ test sample measurement

Data was recalculated in some cases to allow for the variation in insulin response between experiments. These variations were attributed to slight variations in seeding densities, time of cell growth and differentiation of the cells. In these cases, the data were expressed as a percentage of the insulin response (0\%):

$\%$ GU as a function of IR $=$ \% GU of TS - Avg: (\%GU of insulin) $\times 100 \%$

Avg: (\% GU of Insulin)

Key: Avg = average; GU = glucose uptake or utilisation; $\mathrm{IR}=$ insulin response

\section{Glucose utilisation assay in Chang liver cells}

Chang liver cells were seeded into flat-bottom 96-well culture plates (NUNC, Roskilde, Denmark) at a density of 6000 cells/well in a volume of $200 \mu \mathrm{l} /$ well growth medium. After about 72 hours, $10 \mu l$ of fresh growth medium, containing either no additive, metformin ( $1 \mu \mathrm{M}$; Helm AG, Hamburg, Germany) or test sample $(0.125$ or 12.5 $\mu \mathrm{g} / \mathrm{ml}$ ), was added to the $200 \mu \mathrm{l}$ medium already in the well (ethanol extracts contained a maximum of $1.25 \%(\mathrm{v} / \mathrm{v})$ DMSO, which was used for the initial dissolution of these extracts). The final metformin concentration in the medium was $1 \mu \mathrm{M}$ and the extract concentrations were 0.125 and $12.5 \mu \mathrm{g} / \mathrm{ml}$. The cells were exposed to these extracts or metformin for 48 hours before the glucose utilisation assay was done.

On the day of the glucose utilisation assay, incubation buffer (RPMI-1640 diluted with phosphate-buffered saline (PBS) to $8 \mathrm{mM}$ glucose with $0.1 \%(\mathrm{~m} / \mathrm{v})$ bovine serum albumin (BSA; Roche Diagnostics, Germany)) was prepared with and without metformin $(1 \mu \mathrm{M})$ or test sample $(0.5$ or $50 \mu \mathrm{g} / \mathrm{ml})$. The spent growth medium was aspirated from the wells and $50 \mu \mathrm{l}$ of each solution were added per well. The cells were incubated at $37^{\circ} \mathrm{C}$ for a further 3 hours for glucose utilisation to occur.

After three hours of incubation at $37^{\circ} \mathrm{C}$, glucose utilisation was determined as in section 2.3. Concurrently with the glucose assay, a viability assay utilising MTT (Sigma, Germany) was also done in separate wells to detect any possible liver cell toxicity of the test samples during the $48 \mathrm{hr}$ exposure period (Mosmann, 1983). One-hundred microliters of $0.5 \mathrm{mg} / \mathrm{ml}$ MTT in growth medium was added per well and incubated at $37^{\circ} \mathrm{C}$ for 3 hours. At the end of the incubation time, this solution was aspirated and $100 \mu \mathrm{l}$ DSO added to each well to dissolve the formazan crystals formed in the cells. The plate was shaken for 60 seconds to dissolve the formazan salts and read at $540 \mathrm{~nm}$ with a multiplate reader (Multiscan $\mathrm{MS}^{\circledR}$ version 4.0 Labsystem $^{\circledR}$ type 352).

Results were expressed as percentage glucose uptake as compared to control cells of which the glucose uptake was assigned as $100 \%$. Results from the MTT viability assay were taken into account to normalise the data (i.e. to compensate for differences in cell numbers with different extracts).

$$
\begin{aligned}
& \left.\% \mathrm{GU}=\underline{\underline{\text { Avg: }:}} \underline{\underline{0}}-\mathrm{TS}_{492 \mathrm{~nm}}\right) \times 100 \% \quad \times\left(\underline{T S}_{540 \mathrm{~nm}}\right) \\
& \text { [ Avg: (Avg: } \left.\left.\mathrm{T}_{0}\right)-\mathrm{NC}_{492 \mathrm{~nm}} \text { ] (Avg: } \mathrm{NC}_{540 \mathrm{~nm}}\right)
\end{aligned}
$$

Key: $\mathrm{Avg}=$ average; $\mathrm{NC}=$ negative control; $\mathrm{T}_{0}=$ zero time; $\mathrm{TS}=$ test sample

\section{Cytotoxicity assay on Chang liver cells}

Chang liver cells were seeded into flat-bottom 96-well culture plates (NUNC, Roskilde, Denmark) at a density of 6000 cells/well in a volume of $200 \mu \mathrm{l} /$ well growth medium. The next morning, the medium was replaced with $200 \mu \mathrm{l}$ fresh growth medium or growth medium containing different concentrations of crude extracts (125 and $62.5 \mu \mathrm{g} / \mathrm{ml}$ ). Additionally, ethanol extracts contained 0.31 and $0.63 \%(\mathrm{v} / \mathrm{v})$ DMSO (Associated Chemical Enterprises, South Africa) to dissolve the extracts and corresponding negative controls also contained these amounts of DMSO. The cells were exposed to the various buffers for $48 \mathrm{hrs}$ at $37^{\circ} \mathrm{C}$ after which the MTT assay was performed as described above. 
Results are expressed as percentage growth inhibition, taking the growth of the corresponding negative control to be $100 \%$.

$$
\% \mathrm{Gl}=\frac{(\text { Avg: } \mathrm{NC}-\mathrm{T})}{\text { Avg: } \mathrm{NC}} \times 100 \%
$$

Key: Avg = average; $\mathrm{GI}=$ growth inhibition; $\mathrm{NC}=$ negative control readings; $\mathrm{T}$ = sample readings

\section{Statistical analysis}

Results were statistically analysed using GraphPad Prism ${ }^{\circledR} 4$ (Graphpad Software, 2003). Means and standard error of the mean (SEM) values were calculated and used in statistical tests to determine significance. The unpaired t-test was used to compare the negative control values with sample values. Results were considered statistically significant if $p<0.05$. Glucose utilisation responses were further compared to the response of the relative positive control to ascertain if the response produced by the extract were significant or not.

\section{Results}

Table 2 provides a summary of the average percentage glucose uptake achieved in C2C12 muscle cells by aqueous and ethanol extracts $(0.5$ and $50 \mu \mathrm{g} / \mathrm{ml})$. Aqueous extracts that increased glucose utilisation more than insulin included both concentrations of Bulbine frutescens $(130.1 \% ; 121.3 \%)$ and the $0.5 \mu \mathrm{g} / \mathrm{ml}$ concentration of Ornithogalum longibracteatum (129.2\%), Ruta graveolens (124.7\%) and Tarchonanthus camphoratus (128.4\%). Significant concentration-independent responses were observed for $B$. frutescens $(p<0.05)$, O. longibracteatum ( $p<$ $0.005)$ and $T$. camphoratus $(\mathrm{p}<0.05)$. The largest increase in glucose utilisation for ethanol extracts was produced by Tulbaghia violacea $(0.5 \mu \mathrm{g} / \mathrm{ml} ; 140.5 \%)$, which showed a significant concentration-independent response ( $p<$ $0.05)$. The two extracts of $O$. longibracteatum were the only ethanol extracts that produced a concentrationdependent increase in glucose utilisation $(p<0.05)$.

Table 2: Percentage glucose taken up ( \pm SEM) by $\mathrm{C} 2 \mathrm{C} 12$ muscle cells. Cells were treated for one hour with aqueous and ethanol extracts $(0.5$ or $50 \mu \mathrm{g} / \mathrm{ml})$ of Bulbine frutescens, Ornithogalum longibracteatum, Ruta

\begin{tabular}{|c|c|c|c|}
\hline Plant & $\begin{array}{l}\text { Concen- } \\
\text { tration } \\
(\mu \mathrm{g} / \mathrm{ml})\end{array}$ & $\begin{array}{l}\text { Aqueous extracts } \\
\% \text { glucose uptake } \pm \text { SEM }\end{array}$ & $\begin{array}{l}\text { Ethanol extracts } \\
\% \text { glucose uptake } \pm \text { SEM }\end{array}$ \\
\hline Negative control & 0 & $100 \pm 1.53$ & $100 \pm 2.78$ \\
\hline Insulin & $1 \mu \mathrm{M}$ & $119.7 \pm 1.46^{* * *}$ & $117.9 \pm 2.53^{\star \star \star}$ \\
\hline \multirow[t]{2}{*}{ B. frutescens } & 0.5 & $130.1 \pm 2.43^{* \star *}$ & $128.3 \pm 6.65^{\star \star *}$ \\
\hline & 50 & $121.3 \pm 3.05^{* * *}$ & $123.4 \pm 3.41^{* * *}$ \\
\hline \multirow[t]{2}{*}{ O. longibracteatum } & 0.5 & $129.2 \pm 4.19^{* \star \star}$ & $118.3 \pm 5.26^{* *}$ \\
\hline & 50 & $113.9 \pm 2.72^{* \star \star}$ & $133.0 \pm 4.74^{\star * *}$ \\
\hline \multirow[t]{2}{*}{ R. graveolens } & 0.5 & $124.7 \pm 3.30^{* * *}$ & $136.9 \pm 10.85^{\star \star \star}$ \\
\hline & 50 & $118.1 \pm 1.68^{* \star \star}$ & $124.1 \pm 3.74^{\star \star *}$ \\
\hline \multirow[t]{2}{*}{ T. camphoratus } & 0.5 & $128.4 \pm 3.27^{\star \star \star}$ & $131.6 \pm 6.54^{\star \star \star}$ \\
\hline & 50 & $117.4 \pm 2.75^{\star \star \star}$ & $129.7 \pm 4.31^{\star \star \star}$ \\
\hline \multirow[t]{2}{*}{ T. violacea } & 0.5 & $119.0 \pm 2.57^{\star \star \star}$ & $140.5 \pm 5.56^{\star \star \star}$ \\
\hline & 50 & $116.8 \pm 2.203^{* * *}$ & $117.7 \pm 6.66^{\star \star}$ \\
\hline
\end{tabular}
graveolens, Tarchonanthus camphoratus and Tulbaghia violacea at $37^{\circ} \mathrm{C}$.

Averages and $p$-values were calculated with the two-tailed unpaired t-test from three to six experiments per sample and with 12 replicates per sample for each experiment $\left({ }^{*} p<0.05 ;{ }^{* \star} p<0.005 ;{ }^{* \star *} p<0.0005\right)$.

Extracts were also tested in combination with insulin to see whether the combination was more effective in increasing glucose utilisation in $\mathrm{C} 2 \mathrm{C} 12$ muscle cells than when used alone. All glucose utilisation values were recalculated to obtain the percentage response compared to an insulin response of $0 \%$. The $50 \mu \mathrm{g} / \mathrm{ml}$ aqueous extracts of $R$. graveolens $(\mathrm{p}<0.05)$ and $T$. camphoratus $(\mathrm{p}<0.005)$ produced statistically significant increased combined responses as compared to the extracts alone (Figure 1). Additionally, the glucose utilisation activity of the $50 \mu \mathrm{g} / \mathrm{ml}$ concentration of the ethanol extracts of $B$. frutescens $(p<0.05), R$. graveolens $(p<0.05), T$. camphoratus $(p<0.05)$ and $T$. violacea $(p<0.005)$ were significantly potentiated when they were combined with insulin, which may point to an additive or synergistic effect with insulin (Figure 2). However, glucose utilisation activity significantly decreased when insulin was added to the $0.5 \mu \mathrm{g} / \mathrm{ml}$ ethanol extracts of $T$. camphoratus $(\mathrm{p}<0.05)$ and $T$. violacea $(p<0.0005)$ in comparison to the response with these extracts alone. 


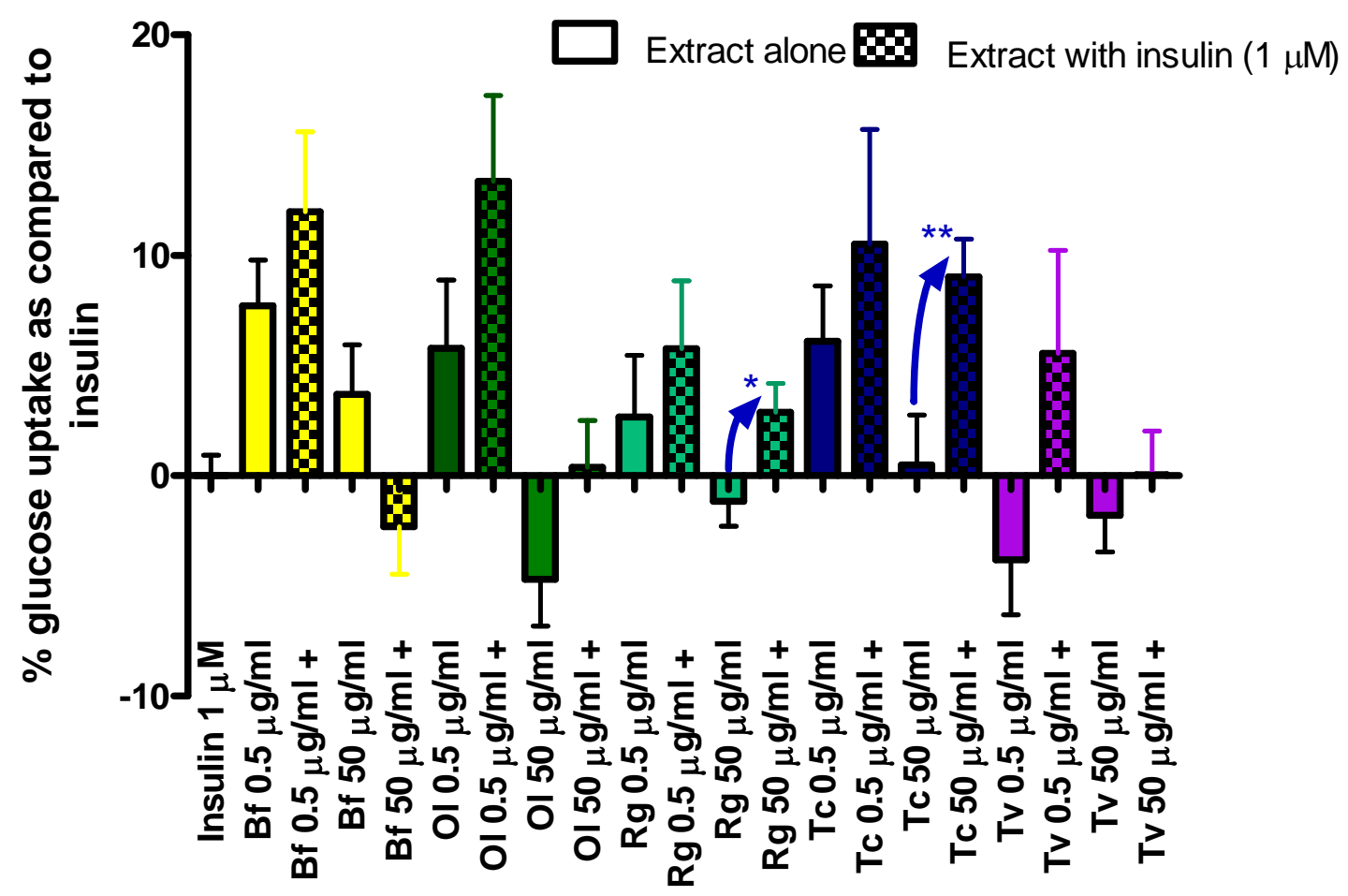

Figure 1: Percentage glucose uptake ( \pm SEM) produced on $\mathrm{C} 2 \mathrm{C} 12$ muscle cells by aqueous extracts with and without insulin as compared to the insulin response (taken as $0 \%$ ). Cells were treated for 1 hour with aqueous extracts $(0.5$ or $50 \mu \mathrm{g} / \mathrm{ml})$ of Bulbine frutescens $(\mathrm{Bf})$, Ornithogalum longibracteatum (Ol), Ruta graveolens $(\mathrm{Rg})$, Tarchonanthus camphoratus (Tc) and Tulbaghia violacea (Tv) and these aqueous extracts combined with insulin $(1 \mu \mathrm{M}$, represented with $\mathrm{a}+)$ at $37^{\circ} \mathrm{C}$. Normal bars represent 10 experiments with 12 replicates per sample for the extract alone and checked bars represent seven individual experiments with the same amount of replicates per sample. The zero gridline indicates percentage glucose uptake of insulin $(1 \mu \mathrm{M})$. Statistical significant changes in response of the extract with and without insulin are indicated with appropriately pointed arrows and stars above the corresponding arrow indicate the degree of significance $\left(p<0.05^{\star}\right.$ and $\left.p<0.005^{\star *}\right)$.

Table 3 provides a summary of the average percentage glucose uptake achieved in Chang liver cells by aqueous and ethanol extracts tested at 0.5 and $50 \mu \mathrm{g} / \mathrm{ml}$. The glucose uptake values were normalised according to cell viability variations (determined by the MTT assay) that might have occurred during the 48 hour exposure period to the different extracts. Aqueous extracts that significantly increased glucose uptake into Chang liver cells were $B$. frutescens $(0.5 \mu \mathrm{g} / \mathrm{ml} ; 143.5 \%)$, O. longibracteatum $(0.5 \mu \mathrm{g} / \mathrm{ml} ; 131.9 \%)$, T. camphoratus $(50 \mu \mathrm{g} / \mathrm{ml} ; 131.5 \%)$ and $T$. violacea $(50 \mu \mathrm{g} / \mathrm{ml} ; 124.5 \%)$. Significant concentration-independent responses were recorded for the aqueous extracts of $B$. frutescens $(p<0.0001)$ and $O$. longibracteatum $(p<0.0005)$ and significant concentration-dependent responses for the aqueous extracts of $T$. camphoratus $(p<0.05)$ and $T$. violacea $(p<0.005)$. The ethanol extract of T. camphoratus $(0.5 \mu \mathrm{g} / \mathrm{ml} ; 126.9 \%)$ produced the greatest glucose utilisation response of the ethanol extracts on Chang liver cells. In summary, the aqueous extracts produced better glucose uptake into Chang liver cells than the ethanol extracts. Interestingly, the aqueous extracts of $B$. frutescens $(0.125 \mu \mathrm{g} / \mathrm{ml})$ and $T$. violacea $(12.5 \mu \mathrm{g} / \mathrm{ml}) \mathrm{were}$ the only to produce significant growth inhibition, although very mild.

Cytotoxicity testing of increased concentrations $(62.5$ and $125 \mu \mathrm{g} / \mathrm{ml})$ of the extracts on Chang liver cells are summarised in Table 4. In this case, ethanol extracts were more cytotoxic than aqueous extracts. The ethanol extract of $B$. frutescens $(62.5 \mu \mathrm{g} / \mathrm{ml})$ produced the largest growth inhibition (33.3\%), followed by $T$. camphoratus (125 $\mu \mathrm{g} / \mathrm{ml} ; 28.05 \%)$ and $T$. violacea $(125 \mu \mathrm{g} / \mathrm{ml} ; 23.3 \%)$. The only aqueous extract that produced significant growth inhibition on Chang liver cells was $O$. longibracteatum $(62.5 \mu \mathrm{g} / \mathrm{ml} ; 18.1 \%)$. 


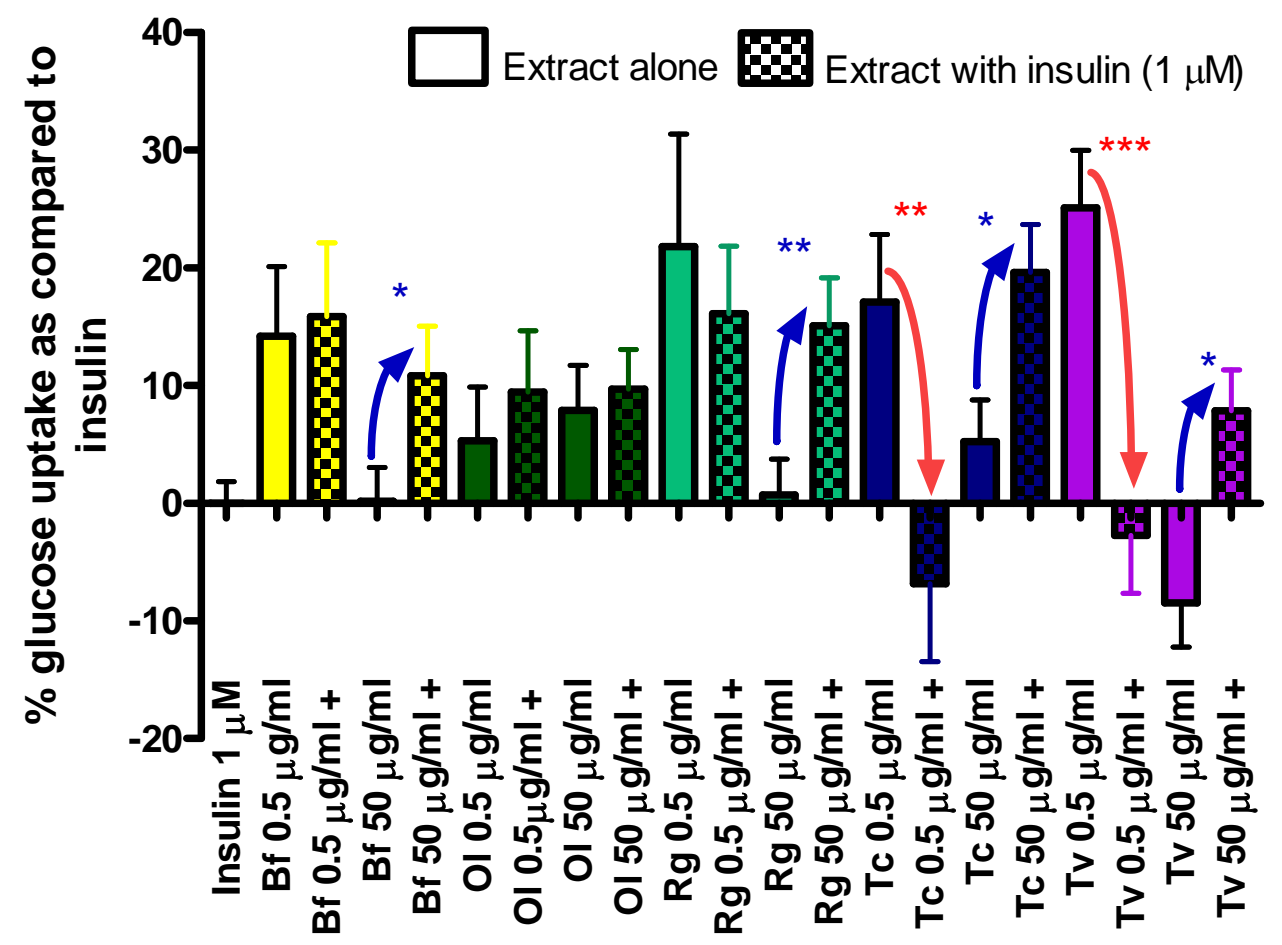

Figure 2: Percentage glucose uptake $( \pm \mathrm{SEM})$ produced on $\mathrm{C} 2 \mathrm{C} 12$ muscle cells by ethanol extracts with and without $1 \mu \mathrm{M}$ insulin as compared to the insulin response (taken as $0 \%$ ). Cells were treated for 1 hour with ethanol extracts $(0.5$ and $50 \mu \mathrm{g} / \mathrm{ml}$ ) of Bulbine frutescens $(\mathrm{Bf})$, Ornithogalum longibracteatum $(\mathrm{Ol})$, Ruta graveolens $(\mathrm{Rg})$, Tarchonanthus camphoratus (Tc) and Tulbaghia violacea (Tv) and these extracts combined with insulin (represented with $\mathrm{a}+$ ) at $37^{\circ} \mathrm{C}$. Normal bars represent two experiments with 12 replicates per sample for the extract alone and checked bars represent two individual experiments per extract with the same amount of replicates per sample. The zero gridline indicates percentage glucose uptake of insulin $(1 \mu \mathrm{M})$. Statistical significant changes in response of the extract with and without insulin are indicated with appropriately pointed arrows and stars above the corresponding arrow indicate the degree of significance $\left(p<0.05^{\star}, p<0.005^{\star \star}\right.$ and $\left.\mathrm{p}<0.0005^{\star \star \star}\right)$.

Table 3: Percentage glucose uptake $( \pm$ SEM) by Chang liver cells. Cells were treated for 48 hours $(0.125$ or 12.5 $\mu \mathrm{g} / \mathrm{ml})$ and again for three hours $(0.5$ or $50 \mu \mathrm{g} / \mathrm{ml})$ with aqueous extracts and ethanol extracts of Bulbine frutescens, Ornithogalum longibracteatum, Ruta graveolens, Tarchonanthus camphoratus and Tulbaghia violacea at $37^{\circ} \mathrm{C}$.

\begin{tabular}{|c|c|c|c|}
\hline Plant & $\begin{array}{l}\text { Concen- } \\
\text { tration } \\
(\mu \mathrm{g} / \mathrm{ml})\end{array}$ & $\begin{array}{l}\text { Aqueous extracts } \\
\% \text { glucose uptake } \pm \text { SEM }\end{array}$ & $\begin{array}{l}\text { Ethanol extracts } \\
\% \text { glucose uptake } \pm \text { SEM }\end{array}$ \\
\hline Negative control & 0 & $100 \pm 1.98$ & $100 \pm 1.71$ \\
\hline Metformin & $1 \mu \mathrm{M}$ & $115.4 \pm 2.23^{\star \star \star}$ & $110.1 \pm 1.83^{\star \star *}$ \\
\hline \multirow[t]{2}{*}{ B. frutescens } & 0.5 & $143.5 \pm 5.69^{\star * *}$ & $110.8 \pm 2.60^{\star \star}$ \\
\hline & 50 & $111.4 \pm 2.40^{*}$ & $104.1 \pm 6.17$ \\
\hline \multirow[t]{2}{*}{ O. longibracteatum } & 0.5 & $131.9 \pm 4.25^{\star \star \star}$ & $106.7 \pm 4.41$ \\
\hline & 50 & $109.5 \pm 2.26^{*}$ & $110.7 \pm 2.08^{* \star}$ \\
\hline \multirow[t]{2}{*}{ R. graveolens } & 0.5 & $114.2 \pm 5.37^{\star \star}$ & $101.3 \pm 2.05$ \\
\hline & 50 & $114.7 \pm 3.45^{\star *}$ & $117.7 \pm 3.07^{\star \star \star}$ \\
\hline \multirow[t]{2}{*}{ T. camphoratus } & 0.5 & $116.7 \pm 5.83^{\star \star}$ & $126.9 \pm 3.84^{\star \star \star}$ \\
\hline & 50 & $131.5 \pm 4.20^{* * *}$ & $101.4 \pm 3.87$ \\
\hline \multirow[t]{2}{*}{ T. violacea } & 0.5 & $98.44 \pm 3.46$ & $100.1 \pm 3.69$ \\
\hline & 50 & $124.5 \pm 7.01^{* * \star}$ & $100.6 \pm 5.73$ \\
\hline
\end{tabular}

Averages and $p$-values were calculated with the two-tailed unpaired t-test from two to three experiments with 10 replicates per sample per experiment $\left({ }^{*} p<0.05 ;{ }^{* \star} p<0.005 ;{ }^{* \star \star} p<0.0005\right)$ 
Table 4: Percentage growth inhibition ( \pm SEM) produced on Chang liver cells. Cells were exposed to aqueous or ethanol extracts $(62.5$ and $125 \mu \mathrm{g} / \mathrm{ml})$ of Bulbine frutescens, Ornithogalum longibracteatum, Ruta graveolens, Tarchonanthus camphoratus and Tulbaghia violacea for $48 \mathrm{hrs}$ at $37^{\circ} \mathrm{C}$.

\begin{tabular}{|c|c|c|c|}
\hline Sample & $\begin{array}{c}\text { Concentration } \\
(\mu \mathrm{g} / \mathrm{ml})\end{array}$ & $\begin{array}{l}\text { Aqueous extracts } \\
\% \text { inhibition } \pm \text { SEM }\end{array}$ & $\begin{array}{c}\text { Ethanol extracts } \\
\% \text { inhibition } \pm \text { SEM }\end{array}$ \\
\hline Negative control & 0 & $0.51 \pm 2.78$ & $-0.18 \pm 3.50$ \\
\hline \multirow[t]{2}{*}{ B. frutescens } & 62.5 & $-9.67 \pm 6.44$ & $33.31 \pm 5.94^{\star \star \star}$ \\
\hline & 125 & $-18.15 \pm 5.10^{\star \star}$ & $30.06 \pm 3.72^{\star \star \star}$ \\
\hline \multirow[t]{2}{*}{ O. longibracteatum } & 62.5 & $18.14 \pm 4.14^{\star \star}$ & $-23.66 \pm 9.09^{*}$ \\
\hline & 125 & $17.53 \pm 5.80^{*}$ & $-15.30 \pm 5.29^{*}$ \\
\hline \multirow{2}{*}{ R. graveolens } & 62.5 & $-22.96 \pm 7.30^{\star \star}$ & $-7.51 \pm 7.63$ \\
\hline & 125 & $-18.71 \pm 7.18^{\star \star}$ & $1.65 \pm 6.24$ \\
\hline \multirow[t]{2}{*}{ T. camphoratus } & 62.5 & $-3.55 \pm 4.51$ & $-9.31 \pm 3.69$ \\
\hline & 125 & $5.56 \pm 4.11$ & $28.05 \pm 3.94^{\star \star \star}$ \\
\hline \multirow[t]{2}{*}{ T. violacea } & 62.5 & $4.65 \pm 2.99$ & $19.38 \pm 5.19^{\star \star}$ \\
\hline & 125 & $6.63 \pm 3.13$ & $23.27 \pm 4.76^{* \star \star}$ \\
\hline
\end{tabular}

Averages and $p$-values were calculated from two to four independent experiments for each sample, with eight replicates per sample per experiment. P-values were calculated using the two-tailed unpaired t-test $\left(^{*} p<0.05 ;{ }^{* *} p<\right.$ $\left.0.005 ;{ }^{* * *} \mathrm{p}<0.0005\right)$.

\section{Discussion}

These scientific findings were communicated to participating traditional health practitioners through feedback seminars. The feedback seminars were based on interactive workshops which were initially used in the collaboration to exchange information regarding disease conditions (van Huyssteen et al., 2004). The seminars described methodology employed in the screenings and subsequent findings as accurately as possible with the assistance of interpreters, demonstrations, photos and translated notes. The interactive nature of the seminars encouraged twoway discussions and practitioners shared that they used Bulbine frutescens and Ornithogalum longibracteatum in their diabetic remedies.

$B$. frutescens and $O$. longibracteatum produced similar glucose utilisation profiles; with $B$. frutescens producing slightly more potent glucose utilisation activity than $O$. longibracteatum. The extracts of $B$. frutescens increased glucose utilisation (except for the ethanol extracts in Chang liver cells) in both cell lines in a concentrationindependent manner. Similar dose-independent responses have been observed for knipholone, one of the active ingredients contained in $B$. frutescens, in a leukotriene biosynthesis assay (Wube et al., 2006). In addition, glucose utilisation was significantly enhanced for the $50 \mu \mathrm{g} / \mathrm{ml}$ ethanol extract when combined with insulin as compared to the response of the extract alone. However, the ethanol extract of $B$. frutescens was found to have toxic effects on the growth of Chang liver cells at concentrations of 62.5 and $125 \mu \mathrm{g} / \mathrm{ml}$.

Apart form the glucose utilisation activity, the aqueous extract of $O$. longibracteatum produced significant, but minor growth inhibitory effects on Chang liver cells $(62.5 \mu \mathrm{g} / \mathrm{ml} ; 18.14 \pm 4.14 \%)$. Concern about the potential toxicity of $O$. Iongibracteatum has been raised (Van Wyk et al., 2002) and toxicity evaluations have provided unequivocal results (Mulholland et al., 2004). The bulb that was extracted for this study was approximately three years old and had flowered during this time. The little toxicity produced in this study seems to support literary observations which suggest that pre-flowering young plants as well as the fruits (Watt and Breyer-Brandwijk, 1962) and leaves (Verschaeve et al., 2004) of the plant are more toxic.

The ethanol extract of Ruta graveolens produced a significant increase in glucose utilisation activity in C2C12 muscle cells. This response might have been caused by the presence of the hypoglycaemic flavanoid, quercetin (Mukherjee et al., 2006), in the $R$. graveolens extracts. In addition, the presence of insulin $(1 \mu \mathrm{M})$ significantly potentiated the glucose utilisation responses for both aqueous and ethanol extracts $(50 \mu \mathrm{g} / \mathrm{ml}) \mathrm{by} 4$ and $14 \%$, respectively as compared to the activity of the extracts alone. Interestingly, the antioxidant action of quercetin (Wube et al., 2006) has been shown to increase insulin sensitivity in muscle cells (Laight et al., 2000). R. graveolens produced no toxicity in any of the screens, except growth stimulation produced by the aqueous extract on Chang liver cells. However, the continued use of $R$. graveolens has been disputed by many scientists due to potential toxicity and serious side-effects induced by this plant (Van Wyk et al., 2002).

Tarchonanthus camphoratus contains many compounds that may be potentially hypoglycaemic, including saponins (Mukherjee et al., 2006), flavanones and tannins (Scott and Springfield, 2005). It was thus interesting to see that the aqueous extracts were more effective at increasing glucose utilisation in Chang liver cells and the ethanol extracts in $\mathrm{C} 2 \mathrm{C} 12$ muscle cells, both following concentration-independent trends. The glucose utilisation responses in $\mathrm{C} 2 \mathrm{C} 12$ muscle cells were significantly influenced by the presence of insulin and this phenomena warrants further investigation. The cytotoxicity trend of the ethanol extracts in Chang liver cells suggests increased 
toxicity with increased concentrations. Participating practitioners also noted that they always used T. camphoratus in combination with other plants to "stop the strongness", despite the fact that they used water in most of their remedies. However, literature reassures that the leaves of $T$. camphoratus are the subject of regular feeding by a variety of wild and domestic animals (Venter and Venter, 2002; Watt and Breyer-Brandwijk, 1962) especially during summer (Parker et al., 2003), which was when the leaves for this study were collected.

The green parts and flowers of Tulbaghia violacea had been consumed as vegetables (Marshalkar, 2003; Roberts, 1990) and more recently, it showed an absence of genotoxicity in the Ames and VITOTOX ${ }^{\circledR}$ tests (Elgorashi et al., 2003). However, cytotoxicity was observed at 62.5 and $125 \mu \mathrm{g} / \mathrm{ml}$ for the ethanol extract on Chang liver cells. At the same time, $T$. violacea contains several ingredients such as steroidal saponins, quercetin, kaempherol, sugars, and / or sulfur-containing compounds (Duncan et al., 1999) that might be considered glucose lowering. Similar sulfurcontaining compounds in garlic have been shown to be hypoglycaemic in diabetic animals and has been ascribed to their anti-oxidant activity and the interaction of these compounds with thiol-containing proteins (Mukherjee et al., 2006). Accordingly, the aqueous extract of $T$. violacea $(50 \mu \mathrm{g} / \mathrm{ml})$ showed significant increased glucose uptake activity into Chang liver cells $(124.5 \%)$ and the ethanol extract $(0.5$ and $50 \mu \mathrm{g} / \mathrm{ml})$ into $\mathrm{C} 2 \mathrm{C} 12$ muscle cells $(140.5 \%$ and $117.7 \%$, respectively). Similar to the ethanol extracts of T. camphoratus, the presence of insulin influenced the glucose utilisation response into muscle cells significantly as compared to the response of the extracts alone.

In returning to an ethnobotanical text, not all the plants in a diabetic remedy may necessarily have antihyperglycaemic activity (Alarcon-Aguilara et al., 1998). Practitioners of this collaboration explained that additional plants used in the remedies were either added to enhance the activity of the active plants or to stop toxic side-effects of another plant. This is in accordance with literature, which states that cytotoxic concerns are often addressed by indigenous cultures through using combinations of very small amounts of different plants in diabetic remedies (Alarcon-Aguilara et al., 1998; Li et al., 2004; Tahraoui et al., 2007; Ziyyat et al., 1997). Accordingly, new trends in ethnopharmacology suggest the investigation of synergy between plants in remedies (Gilani and Atta-ur-Rahman, 2005). Recent evidence on the pathology of diabetes suggests an increasing amount of targets that might prolong the onset of type 2 diabetes mellitus (T2DM) ie. treating causes of insulin resistance, inflammation, the procoagulative state, obesity etc. In light of this, natural products or crude extracts of natural products may exhibit more than one mechanism which may potentially (Raghav et al., 2006) prolong the development, improve treatment and/or prevent complications of T2DM. In conclusion, the favourable glucose utilisation profiles of most of the plants tested in the study highlights the potential effectiveness of traditional remedies in the management for diabetes mellitus. However, preliminary toxicity results reinforce the need to determine optimal and safe dosing measurements if these remedies are to be used.

\section{Acknowledgements}

We acknowledge National Research Foundation and Medical Research Council of South Africa for funding of the project (FA2006021600006). We would like to acknowledge the following healers and organisations for their involvement in the research collaboration; Fezeka Kosi and members of Nyangazezizwe Traditional Healers Assosiation, members of Traditional Health Practitioners: Nelson Mandela Bay Metro and Tandiwe Mazamane and members of the Eastern Cape Task Team.

\section{References}

1. Alarcon-Aguilara, F. J., Roman-Ramos, R., Perez-Gutierrez, S., Aguilar-Contreras, A., Contreras-Weber, C. C. and Flores-Saenz, J. L. (1998). Study of the anti-hyperglycemic effect of plants used as antidiabetics. J. Ethnopharmacol. 61: 101-109.

2. Cox, P. A. and Ballick, M. J. (1994). The ethnobotanical approach to drug discovery. Sci. Am. June: 60-65.

3. Duncan, A. C., Jager, A. K. and van Staden, J. (1999). Screening of Zulu medicinal plants for angiotensin converting enzyme (ACE) inhibitors. J. Ethnopharmacol. 68: 63-70.

4. Elgorashi, E. E., Taylor, J. L. S., Maes, A., van Staden, J., De Kimpe, N. and Verschaeve, L. (2003). Screening of medicinal plants used in South African traditional medicine for genotoxicity. Toxicol. Lett. 143: 195-207.

5. Eloff, J. N. (1998). Which extractant should be used for the screening and isolation of antimicrobial components from plants? J. Ethnopharmacol. 60: 1-8.

6. Gilani, A. H. and Atta-ur-Rahman. (2005). Trends in ethnopharmacology. J. Ethnopharmacol. 100: 43-49.

7. GraphPad Software. (2003). GraphPad PRISM ${ }^{\circledR}$. GraphPad Software Inc.

8. Grierson, D. S. and Afolayan, A. J. (1999). An ethnobotanical study of plants used for the treatment of wounds in the Eastern Cape, South Africa. J. Ethnopharmacol. 67: 327. 
9. Inngjerdingen, K., Nergrad, C. S., Diallo, D., Mounkoro, P. P. and Smestad, B. (2004). An ethnopharmacological survey of plants used for wound healing in Dogonland, Mali, West Africa. J. Ethnopharmacol. 92: 233-244.

10. Kelmanson, J. E., Jäger, A. K. and van Staden, J. (2000). Zulu medicinal plants with antibacterial activity. J. Ethnopharmacol. 69: 241-246.

11. Laight, D. W., Carrier, M. J. and Anggard, E. E. (2000). Antioxidants, diabetes and endothelial dysfunction. Cardiovasc. Res. 47: 457-464.

12. Li, W. L., Zheng, H. C., Bukuru, J. and De Kimpe, N. (2004). Natural medicines used in the traditional Chinese medical system for therapy of diabetes mellitus. J. Ethnopharmacol. 92: 1-21.

13. Louw, C. A. M., Regnier, T. J. C. and Korsten, L. (2002). Medicinal bulbous plants of South Africa and their traditional relevance in the control of infectious diseases. J. Ethnopharmacol. 82: 147-154.

14. Marshalkar, R. A. (2003). Photographic guide to the wildflowers of South Africa. Briza Publishers, Pretoria, South Africa, pp.138.

15. Molleutze, W. F. and Levitt, N. S. (2005). Diabetes mellitus and impaired glucose tolerance in South Africa; Chapter 10 from Chronic diseases of lifestyle in South Africa since 1995 - 2005. www.mrc.ac.za/Chronic/cdl1995-2005.pdf, (Date accessed: 22 November 2006).

16. Mosmann, T. (1983). Rapid colorimetric assay for cellular growth and survival: Application to proliferation and cytotoxicity assays. J. Immunol. Methods. 65: 55-63.

17. Motsei, M. L., Lindsey, K. L., van Staden, J. and Jäger, A. K. (2003). Screening of traditionally used South African plants for antifungal activity against Candida albicans. J. Ethnopharmacol. 86: 235-241.

18. Mukherjee, P. K., Maiti, K., Mukherjee, K. and Houghton, P. J. (2006). Leads from Indian medicinal plants with hypoglycemic potentials. J. Ethnopharmacol. 106: 1-28.

19. Mulholland, D. A., Crouch, N. R., Pohl, T. L. and Ndlovu, E. (2004). A homoisoflavone from Ornithogalum longibracteatum (Ornithogaloideae: Hyacinthaceae). Biochem. Syst. Ecol. 32: 499-502.

20. Parker, D. M., Bernard, R. T. F. and Colvin, S. A. (2003). The diet of a small group of extralimital giraffe. Afr. J. Ecol. 41: 245-253.

21. Raghav, S. K., Gupta, B., Agrawal, C., Goswami, K. and Das, H. R. (2006). Anti-inflammatory effect of Ruta graveolens L. in murine macrophage cells. J. Ethnopharmacol. 104: 234-239.

22. Roberts, M. (1990). Indigenous healing plants. Southern Book Publishers, Halfway House, South Africa, pp. 233.

23. Scott, G. and Springfield, E. (2005). Tarchonanthus camphoratus herba. www.plantzafrica.com/medmonographs/tarchonanthcamp.pdf, (Date accessed: October 2005).

24. Shale, T. L., Stirk, W. A. and van Staden, J. (1999). Screening of medicinal plants used in Lesotho for antibacterial and anti-inflammatory activity. J. Ethnopharmacol. 67: 347-354.

25. Tahraoui, A., El Hilaly, J., Israili, Z. H. and Lyoussi, B. (2007). Ethnopharmacological survey of plants used in the traditional treatment of hypertension and diabetes in south-eastern Morocco (Errachidia province). J. Ethnopharmacol. 110: 105-117.

26. Thring, T. S. A. and Weitz, F. M. (2006). Medicinal plant use in the Bredasdorp/Elim region of the Southern Overberg in the Western Cape Province of South Africa. J. Ethnopharmacol. 103: 261-275.

27. Van Huyssteen, M., Reddy, M., Naidoo, N. T., Boschmans, S-A., McCartney, J. and van de Venter, M. (2004). Awareness of diabetes mellitus among African traditional healers in the Nelson Mandela Metropole. Health SA Gesondheid 9: 27-35.

28. Van Wyk, B-E., Van Heerden, F. and Van Oudtshoorn, B. (2002). Poisonous plants of South Africa. Briza Publications, Pretoria, South Africa, pp. 24.

29. Venter, F. and Venter, J-A. (2002). Making the most of indigenous trees. Briza Publications, Pretoria, South Africa.

30. Verschaeve, L., Kestens, V., Taylor, J. L. S., Elgorashi, E. E., Maes, A., Van Puyvelde, L., De Kimpe, N. and van Staden, J. (2004). Investigation of the antimutagenic effects of selected South African plant extracts. Toxicol. in. Vitro. 18: 29-35.

31. Watt, J. M. and Breyer-Brandwijk, M. G. (1962). The medicinal and poisonous plants of Southern and Eastern Africa. E \& S Livingstone Ltd, Edinburgh, Great Brittain, pp. 923.

32. Wube, A. A., Bucar, F., Asres, K., Gibbons, S., Adams, M., Streit, B., Bodensieck, A. and Bauer, R. (2006). Knipholone, a selective inhibitor of leukotriene metabolism. Phytomedicine. 13: 452-456.

33. Ziyyat, A., Legssyer, A., Mekhfi, H., Dassouli, A., Serhrouchni, M. and Benjelloun, W. (1997). Phytotherapy of hypertension and diabetes in oriental Morocco. J. Ethnopharmacol. 58: 45-54. 